\title{
Assisted dying around the world: a status quaestionis
}

\author{
Sarah Mroz ${ }^{1}$, Sigrid Dierickx ${ }^{1,2}$, Luc Deliens ${ }^{1,2}$, Joachim Cohen $^{1 \#}$, Kenneth Chambaere $^{1,2 \#}$ \\ ${ }^{1}$ End-of-life Care Research Group, Vrije Universiteit Brussel (VUB) \& Ghent University, Brussels, Belgium; ${ }^{2}$ Department of Public Health and \\ Primary Care, Ghent University, Brussels, Belgium \\ Contributions: (I) Conception and design: S Mroz, K Chambaere, L Deliens; (II) Administrative support: None; (III) Provision of study materials or \\ patients: None; (IV) Collection and assembly of data: None; (V) Data analysis and interpretation: None; (VI) Manuscript writing: All authors; (VII) \\ Final approval of manuscript: All authors. \\ \#These authors contributed equally to this work. \\ Correspondence to: Sarah Mroz. End-of-Life Care Research Group, Vrije Universiteit Brussel (VUB) \& Ghent University, Laarbeeklaan 103 , 1090 \\ Brussels, Belgium. Email: Sarah.Christine.Mroz@vub.be.
}

\begin{abstract}
Assisted dying practices, which include euthanasia and physician-assisted suicide (PAS), have expanded significantly around the world over the past 20 years. Euthanasia refers to the act of intentionally ending the life of a patient by a health care practitioner through medical means at that patient's explicit request while PAS involves the provision or prescribing of drugs by a health care practitioner for a patient to end their own life. The growing global aging population accompanied by higher levels of chronic disease and protracted illnesses have sharpened the focus on end of life issues and societal and legislative debates continue to address related moral and ethical complexities. Assisted dying practices are now legal in 18 jurisdictions, increasing the number of people with access to euthanasia and/or physician-assisted suicide (PAS) to over 200 million. New legislation is being crafted or considered in Portugal, Spain and 16 US states. Germany has recently overturned a ban on assisted dying services and New Zealand will put legalization of euthanasia to a vote in 2020. Assisted dying practice characteristics differ and there is also considerable variation in the terminology and labels used for assisted dying, which can add to the confusion and controversy around the practices. Frequency of use also varies greatly by jurisdiction, though a consistent increase has been seen in European countries including Belgium, the Netherlands and Switzerland as well as some jurisdictions with long-standing physician assisted dying laws, such as Oregon and Washington. All assisted dying legislation includes substantive and procedural requirements, such as minimum age, waiting period, health condition, physician consultation and reporting procedure, however, some are extensive and detailed while others are more limited. As access to assisted dying expands in new and existing jurisdictions, research must also expand to diligently examine the impact on patients, specifically among vulnerable populations, as well as on health care practitioners, health care systems and communities. This article will provide a thorough investigation, or 'status quaestionis' of the terminology, evolution and current legislative picture of assisted dying practices around the globe and contribute to the ongoing ethical, regulatory and practice debate, which have become increasingly important considerations for medical practice, end-of-life care and public health.
\end{abstract}

Keywords: Assisted dying; end of life; physician assisted suicide; euthanasia; medical aid in dying

Submitted Mar 13, 2020. Accepted for publication Aug 11, 2020.

doi: 10.21037/apm-20-637

View this article at: http://dx.doi.org/10.21037/apm-20-637 


\section{Introduction}

In developed nations, chronic conditions such as cancer and cardiovascular disease are leading causes of death. These conditions are sometimes associated with long and debilitating trajectories complicated by the use of medicaltechnological interventions, which can extend life but can also lead to protracted suffering $(1,2)$. Disease-associated pain, suffering, functional and cognitive decline and associated experiences of loss of dignity and autonomy motivate some people to wish for hastened death $(1,3)$. Increasing public discourse around patient autonomy, quality of life and what constitutes a 'good death' is also impacting perceptions and support for assisted dying legislation in a growing number of countries.

Assisted dying practices, which include euthanasia and PAS, have become increasingly important considerations for medical practice, end-of-life care and public health $(3,4)$. Euthanasia refers to the act of intentionally ending the life of a patient by a health care practitioner by means of active drug administration at that patient's explicit request. PAS is similar to euthanasia but involves the provision or prescribing of drugs by a health care practitioner for a patient to use to end their own life (5). The term "assisted dying" is used in this article as an umbrella term referring to both the practice of euthanasia and PAS. This article will provide an overview of the terminology, evolution and current legislative picture of assisted dying practices around the globe.

\section{Labelling and definitions vary by jurisdiction or country}

The modern meaning of the term euthanasia began in the $20^{\text {th }}$ century with the growth of the right-to-die organizations and voluntary euthanasia organizations who supported legalization of the practice (5). The debate around euthanasia was reinvigorated in 1973 by a legal case in the Netherlands involving a physician who used a lethal injection to end the life of her dying mother at her mother's request (6). The physician's light sentencing led to increased legal deliberation and tolerance in the Netherlands, where eventually euthanasia was legalized in 2002 (6).

The term "passive euthanasia" was often previously used to refer to passive decisions, including withholding or withdrawing life-sustaining or life-prolonging treatment, however this use leads to confusion and is not accurate given that 'euthanasia' is legally defined as active and voluntary in countries with such legislation (5). In the US and elsewhere, termination of potentially life sustaining treatments is considered ethical and legal when carried out with the patient or proxy's agreement (7). Referring to acts that are outside a patient's request as "non-voluntary euthanasia" or "involuntary euthanasia", are likewise unsuitable as these terms refer to the act of administering lethal drugs without the patient's explicit request, which falls outside the definition of euthanasia (5). In most European countries, cases involving involuntary and nonvoluntary death are referred to as "termination of life without the patient's explicit request" (7).

The labelling and legal definitions of euthanasia or PAS vary by country and are debated (7). Various terms are used to refer to assisted dying practices including: euthanasia, PAS, medically assisted suicide, physician-assisted dying, voluntary assisted dying (VAD), physician aid in dying and medical aid in dying $(7,8)$. The meaning and use of these terms are not consistent or universally agreed upon, which results in ongoing confusion and adds to the controversy surrounding them $(9,10)$. The term physician-assisted dying is frequently used, particularly in Europe (7). There is ongoing debate in the United States about which term is most appropriate to refer to assisted dying. The term PAS has been commonly used, however, there has been a shift toward use of medical aid in dying and it is seen more frequently in scientific literature and legislation, along with the term death with dignity $(8,11)$. Medical-aid-in dying (MAiD) is used to refer to both the practices of euthanasia and assisted suicide and is commonly used in Canada, where both a physician and nurse practitioner are allowed to perform the practices $(5,12)$. In Australia, the term VAD is used for the practice of physician-assisted dying, and the law prioritizes PAS above euthanasia. Health care practitioners can only use euthanasia when the patient has a medical condition that excludes PAS, for example, when the patient can no longer swallow.

The variation and confusion associated with assisted dying terminology is likely influenced and compounded by a range of factors including the use of qualifiers, such as active and passive when speaking about euthanasia, the desire to avoid terms like euthanasia and suicide based on concerns that they are morally or emotionally loaded or inaccurate, and overlapping or ambiguous terms such as medical assistance in dying, which could be used to reference both PAS and euthanasia $(8,9,13)$. Research has indicated that public attitudes on assisted dying are embedded in cultural, religious and spiritual traditions and historical experience, 
which also likely impacts the terminology used to reference these practices within the socio-cultural context in various jurisdictions (13).

\section{Background and current legal status worldwide}

Euthanasia is currently legal in seven jurisdictions: the Netherlands (since 2002), Belgium (since 2002), Luxemburg (since 2009), Colombia (since 2015), Canada (since 2016) and Victoria (since 2017) and Western Australia (since 2019) in Australia (Table 1). Western Australia passed euthanasia legislation as of December 2019 with an 18-month implementation phase before the law comes into effect in mid-2021 (14). As of February 2020, the Spanish legislature is debating a bill that would legalize euthanasia and assisted suicide and similar legislation is being crafted in Portugal following the approval of related proposals by parliament $(15,16)$. New Zealand's parliament voted in favor of legalizing euthanasia in late 2019 and a national referendum on the issue will take place in September 2020 (17).

The Northern Territory in Australia was the first jurisdiction to legalize euthanasia in 1995, however, the law was overturned after just nine months by the federal Parliament of Australia (5). Prior to legalization in the Netherlands, there was a period of legal tolerance of euthanasia between the mid-1980s and 2001, provided that specific practice requirements were fulfilled as outlined by the Royal Dutch Medical Association (5). Both the Netherlands and Belgium legalized euthanasia in 2002, and Luxembourg followed in 2009 (7). Colombia is the only country in Latin America that permits assisted dying and it is the only jurisdiction that requires the approval of an independent committee prior to euthanasia being performed $(7,18)$. Although the Colombian Constitutional Court decriminalized "mercy homicide" in 1997, process rules were not put into place until 2015 (18). The legalization of euthanasia in Canada came as a result of the Supreme Court case Carter vs. Canada and provinces were required to draft laws legalizing euthanasia by February 2016, which was later delayed to June 2016. In the Australian state of Victoria, euthanasia and assisted suicide are allowed by law via the Voluntary Assisted Dying Bill of 2017, effective as of June 2019 (5).

PAS without the option for euthanasia, is legally practiced in Switzerland and ten US jurisdictions. In 1942, Switzerland indicated in its penal code that assisting in a suicide is not considered a crime as long as there are no covetous motivations, such as seeking to gain inheritance (7).
Since the 1980s, right-to-die organizations have been interpreting the law as legal permission to operate organizations to support people who wish to obtain assisted suicide, including nonresidents (7). In 2006, the Federal Court of Switzerland extended the law to include those with mental disorders and imposed standardized process rules requiring increased documentation and reporting from the organizations that provide assisted suicide (19). After efforts to legalize euthanasia in the United States in the early 1900s failed, it wasn't until the 1980s and the promotion of pathologist, Dr. Jacob "Jack" Kevorkian that the national conversation was renewed (8). Fierce public debate led to several court cases and eventually the US Supreme Court ruled that right-to-die decisions would be left to the states (8). Since 1997, PAS has been legalized in nine US states and one district: Oregon (Death with Dignity Act; 1997), Washington (Death with Dignity Act; 2009), Montana (by Supreme Court ruling; 2009), Vermont (Patient Choice and Control at the End of Life Act; 2013), California (End of Life Option Act; 2016), Colorado (End of Life Options Act; 2016), District of Columbia (D.C. Death with Dignity Act; 2017), Hawaii (Our Care, Our Choice Act; 2019), Maine (Death with Dignity Act; 2019), New Jersey (Aid in Dying for the Terminally Ill Act; 2019). Sixteen other states are considering death with dignity laws in 2020, or the current legislative session, including: Utah, Arizona, Minnesota, Iowa, Wisconsin, Indiana, Kentucky, Georgia, Florida, Virginia, Maryland, New York, Connecticut, Rhode Island, Massachusetts, New Hampshire (11). In February 2020, the German supreme court overturned a law banning the provision of assisted suicide services, which includes prescribing lethal doses of sedatives to terminally ill patients and providing consultation on how to legally access life-ending assistance in other countries (20).

\section{Legal requirements and safeguards}

Every jurisdiction that has legalized euthanasia and/or physician-assisted suicide has implemented substantive and procedural requirements and safeguards (5) (Table 2). Most jurisdictions impose minimum age restrictions for euthanasia and physician-assisted suicide to be permissible (7). In Canada, Luxembourg and the United States, a person must be at least 18 years old to request physician-assisted suicide (7). In the Netherlands, a patient can request assisted dying from the age of 12 years old (7). Belgium has allowed a patient of any age to request euthanasia or 


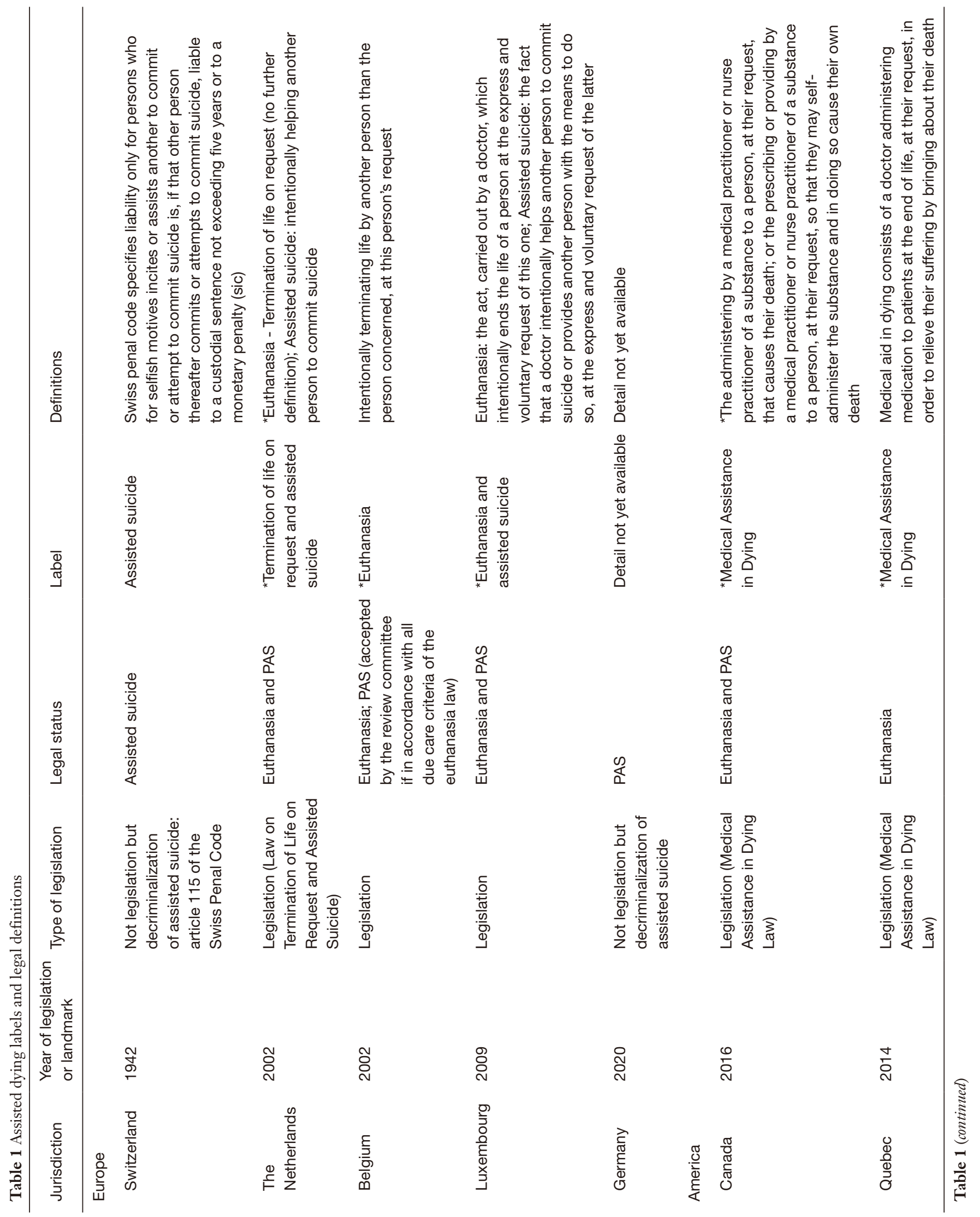




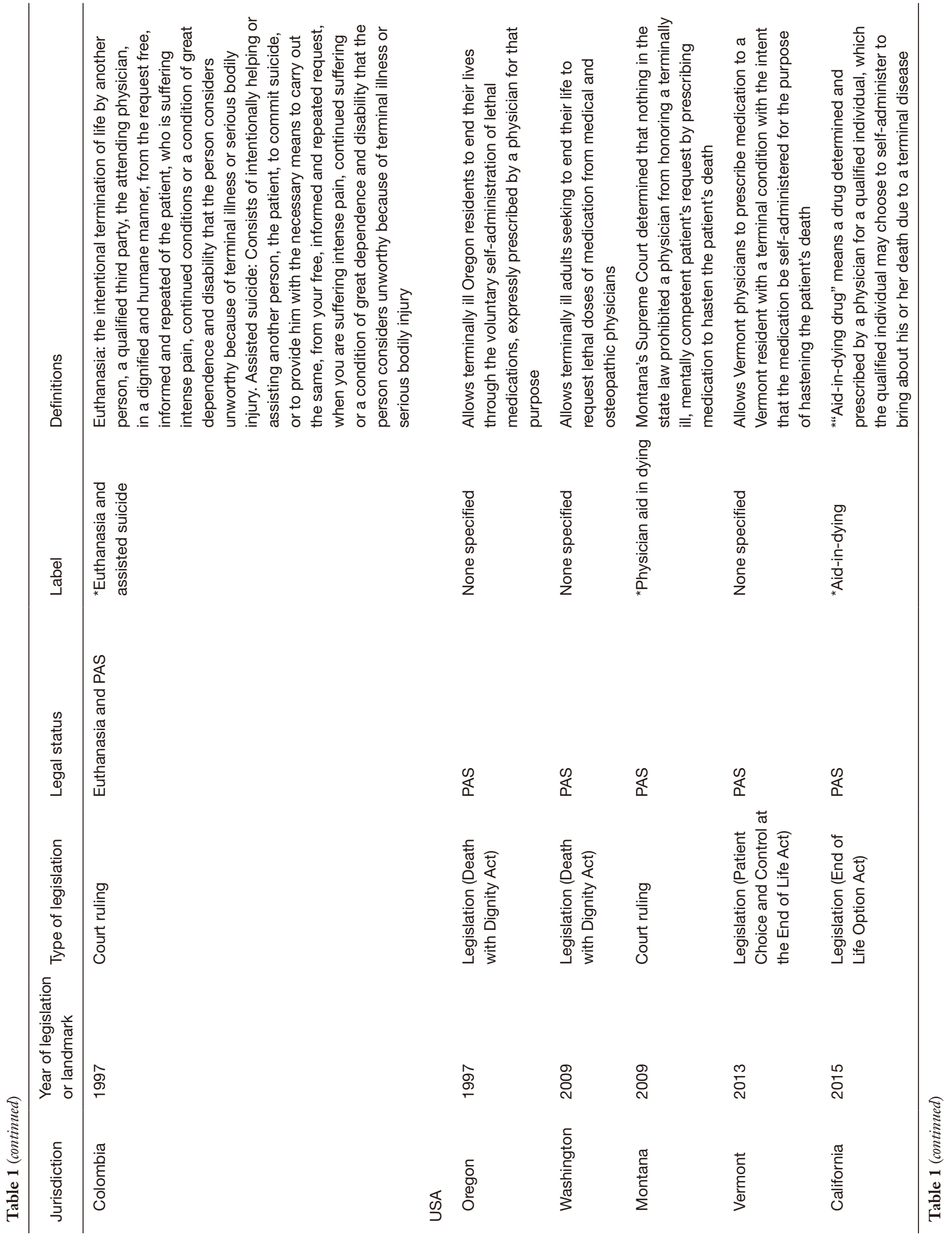




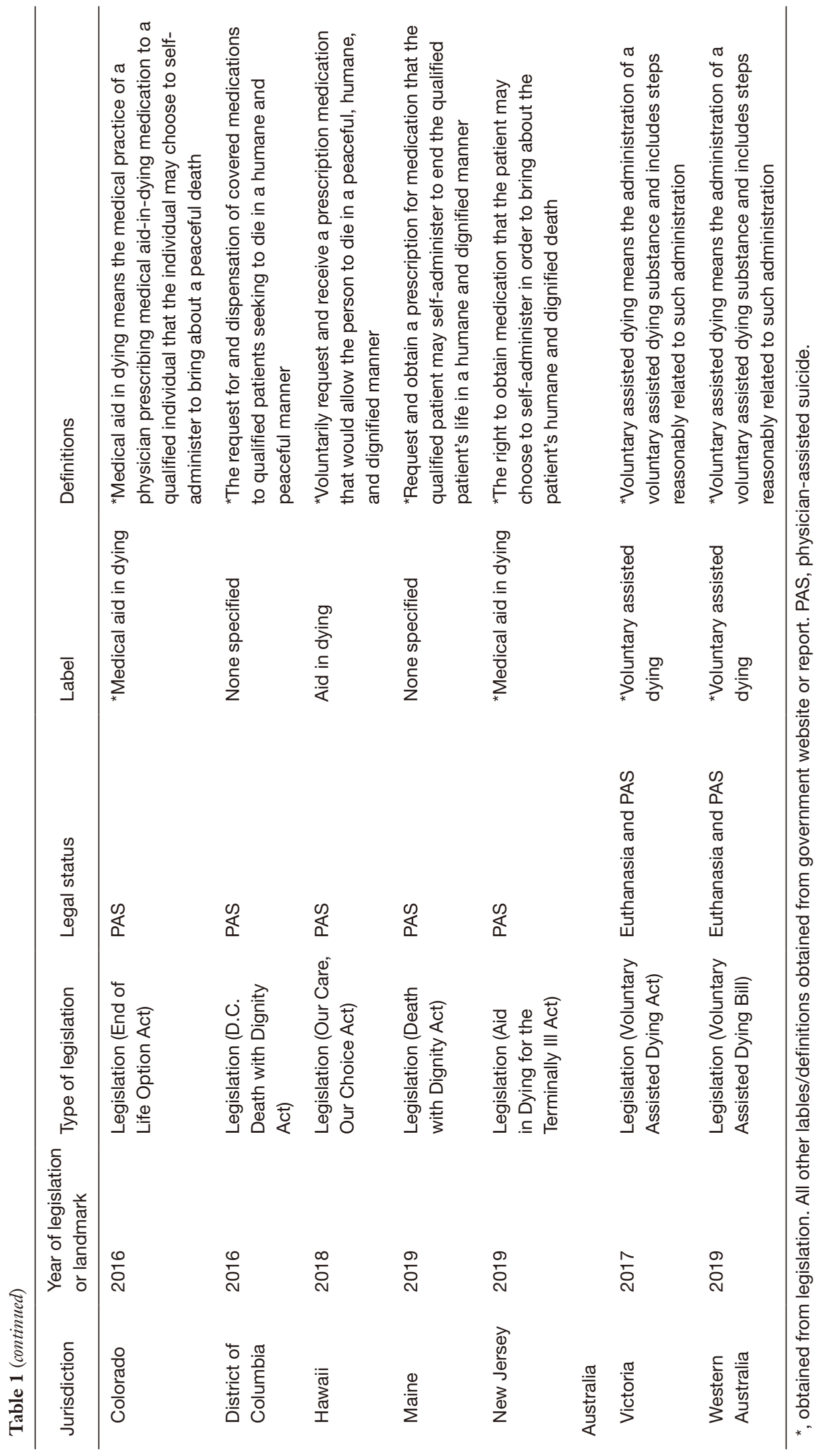


Table 2 Assisted dying legal requirements and safeguards

\begin{tabular}{|c|c|c|c|c|c|c|c|}
\hline Jurisdiction & Euthanasia & PAS & $\begin{array}{l}\text { Age } \\
\text { requirement }\end{array}$ & $\begin{array}{l}\text { Diagnosis/prognosis } \\
\text { required }\end{array}$ & $\begin{array}{l}\text { Waiting period } \\
\text { required }\end{array}$ & $\begin{array}{l}\text { Peer } \\
\text { consultation } \\
\text { required }\end{array}$ & $\begin{array}{l}\text { Commmittee } \\
\text { review }\end{array}$ \\
\hline Switzerland & No & Yes & $\begin{array}{l}\text { None } \\
\text { specified }\end{array}$ & None specified & None specified & None specified & None specified \\
\hline Belgium & Yes & $\begin{array}{l}\text { Not legal } \\
\text { (but } \\
\text { condoned) }\end{array}$ & $\begin{array}{l}\text { None } \\
\text { specified }\end{array}$ & $\begin{array}{l}\text { Adults: incurable } \\
\text { condition; minors: } \\
\text { terminal }\end{array}$ & $\begin{array}{l}\text { None, terminal } \\
1 \text { month, non } \\
\text { terminal }\end{array}$ & Yes & Yes \\
\hline Luxembourg & Yes & Yes & 18 & Incurable condition & None specified & Yes & Yes \\
\hline \multicolumn{8}{|l|}{ America } \\
\hline Quebec & Yes & No & 18 & $\begin{array}{l}\text { Serious, incurable } \\
\text { illness }\end{array}$ & $\begin{array}{l}10 \text { days written } \\
\text { request }\end{array}$ & Yes & No \\
\hline Colombia & Yes & Yes & 18 & Terminal & $\begin{array}{l}\text { Within } 15 \text { days } \\
\text { after committee } \\
\text { approval }\end{array}$ & $\begin{array}{l}\text { Committee } \\
\text { approval } \\
\text { required }\end{array}$ & $\begin{array}{l}\text { Yes, before } \\
\text { euthanasia or } \\
\text { PAS performed }\end{array}$ \\
\hline \multicolumn{8}{|l|}{ USA } \\
\hline Oregon & No & Yes & 18 & Terminal, $<6$ months & $\begin{array}{l}15 \text { days oral } \\
\text { request, } 48 \text { hours } \\
\text { written request }\end{array}$ & Yes & None specified \\
\hline California & No & Yes & 18 & Terminal, $<6$ months & $\begin{array}{l}15 \text { days oral } \\
\text { request }\end{array}$ & Yes & None specified \\
\hline Colorado & No & Yes & 18 & Terminal, $<6$ months & $\begin{array}{l}15 \text { days oral } \\
\text { request }\end{array}$ & Yes & None specified \\
\hline $\begin{array}{l}\text { District of } \\
\text { Columbia }\end{array}$ & No & Yes & 18 & Terminal, $<6$ months & $\begin{array}{l}15 \text { days oral } \\
\text { request, } 48 \text { hours } \\
\text { written request }\end{array}$ & Yes & None specified \\
\hline Hawaii & No & Yes & 18 & Terminal, $<6$ months & $\begin{array}{l}20 \text { days oral } \\
\text { request, } 48 \text { hours } \\
\text { written request }\end{array}$ & Yes & None specified \\
\hline Maine & No & Yes & 18 & Terminal, $<6$ months & $\begin{array}{l}17 \text { days oral } \\
\text { request, } 48 \text { hours } \\
\text { written request }\end{array}$ & Yes & None specified \\
\hline
\end{tabular}

Table 2 (continued) 
Table 2 (continued)

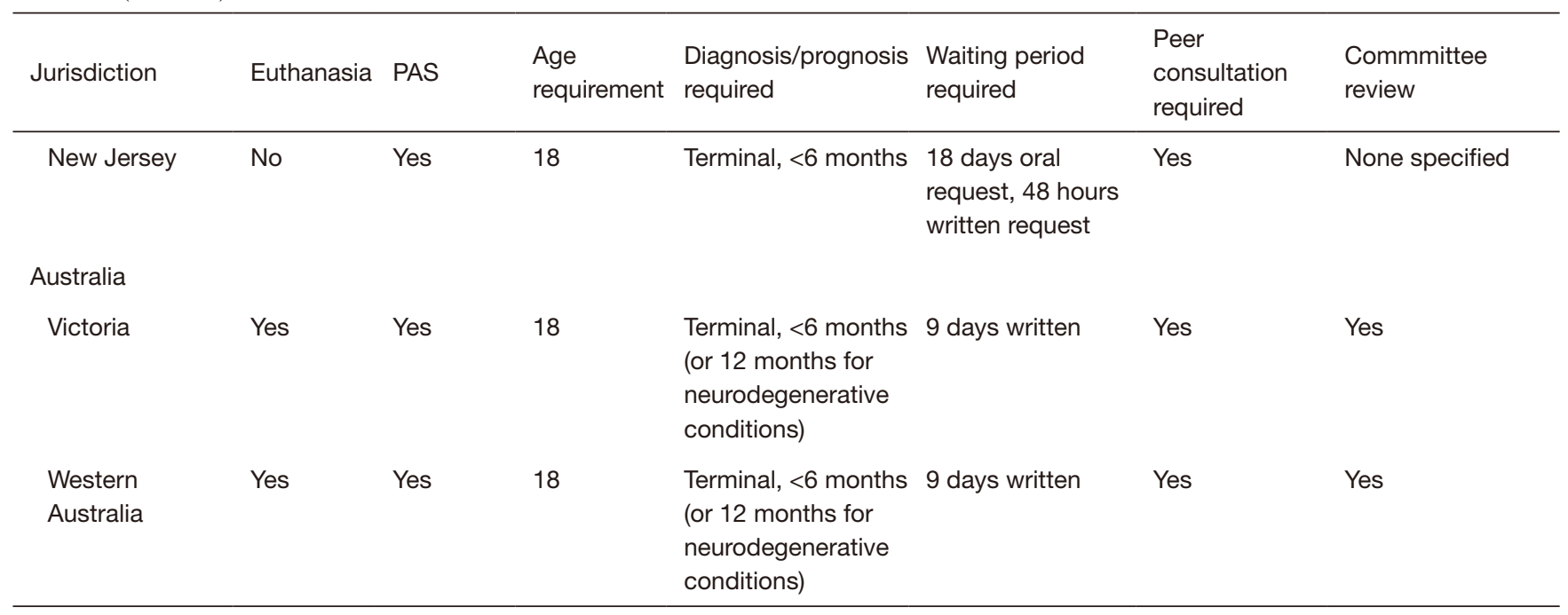

PAS, physician-assisted suicide.

physician-assisted suicide since 2014, provided they are of mature judgement (7). Switzerland does not specify an age at which a person can request assisted suicide though most right-to-die organizations require the person to be an adult with sound judgement (21).

While assisted dying legislation in the Netherlands and Belgium are functionally similar and the prescribed safeguards are limited in number, other jurisdictions like Western Australia have extensive detailed requirements related to access, eligibility (for those making requests and the practitioners handling requests), notification, referral, assessment, documentation and reporting. The level of specificity included in the legislation goes well beyond that of the law passed in 2017 in the Australian state of Victoria, which was already fairly extensive. Legislation for MAiD in Canada is similarly succinct to the European laws and does not include a diagnosis requirement but does require a waiting period of 10 days, unlike laws in the Netherlands, Belgium and Luxembourg. Variation among assisted dying laws has significant implications for patients, physicians and health care systems relative to access, care delivery and reporting. It is also an important consideration impacting cross-national comparison of assisted dying practice and incidence. Although variability exists, there are some similarities in the substantive and procedural safeguards between jurisdictions $(5,7)$.

Commonalities among substantive requirements for assisted suicide and euthanasia include:

* The request must be voluntary, thoroughly considered and sustained/repeated over time;

* The person must have a serious and incurable condition caused by an illness or an accident (in the US, Colombia, and Victoria the person must also be expected to die imminently);

* The person must have unbearable physical or psychological suffering which cannot be alleviated (not required for PAS in the US);

* The physician must inform the person about their condition and medical options and both parties must have reached the understanding that no reasonable likelihood of improvement exists.

Commonalities among procedural requirements for assisted suicide and euthanasia include:

* A second independent physician must by consulted by the treating physician before euthanasia is performed (a third consultation is required for nonterminal cases in Belgium);

* The US and Canada require mandatory waiting periods between request and provision of assisted death;

* Euthanasia must be reported by the physician following the procedure for review by a multidisciplinary control and evaluation committee (in Colombia this must be done prior to euthanasia being carried out) 


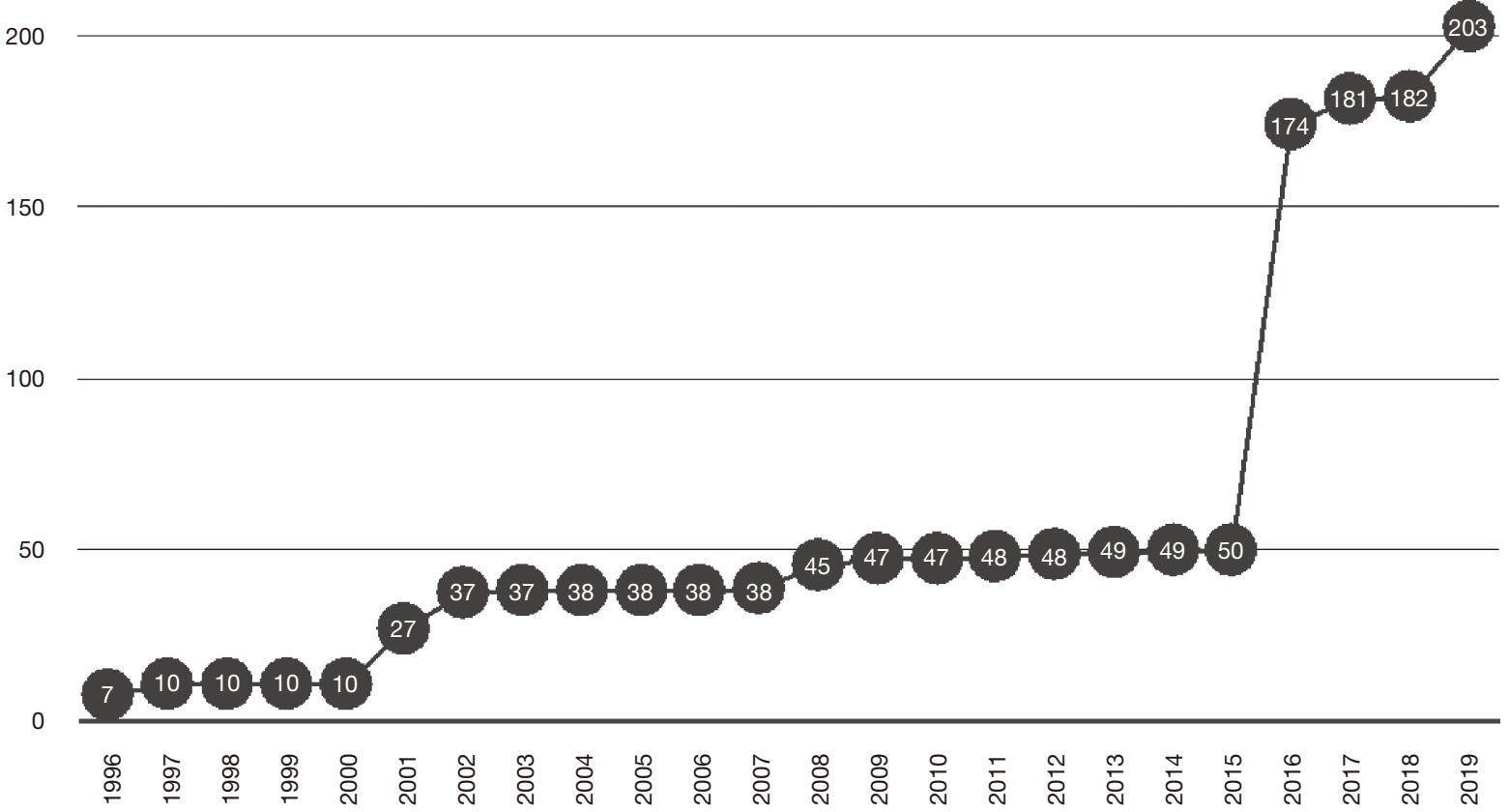

Figure 1 World population under assisted dying law.

\section{What do we know to date about assisted dying practice?}

Assisted dying practices and their consequences have been investigated for nearly thirty years (7). While euthanasia and physician-assisted suicide remain controversial and societal and legislative debates continue, over 200 million people around the world are now living in jurisdictions allowing some form of assisted dying (Figure 1) and many more states and countries are considering legalization $(2,7)$. While practice characteristics vary by jurisdiction and existing laws require close monitoring, those without laws can benefit from the experiences of others to fuel societal debate and research data continues to be imperative.

\section{Motivation for requests and patient demographics}

Studies indicate that pain is not typically the primary motivation for requesting euthanasia or physician-assisted suicide; inadequate pain control is seen in less than $33 \%$ of patients (7). Loss of autonomy, diminished quality of life and loss of dignity are the factors most frequently associated with requests for assisted dying (22). Loss of dignity is identified as the basis for requests in $61 \%$ of cases in the Netherlands and 52\% in Belgium (7). Patients who request euthanasia or assisted suicide are most often dying of cancer (60-100\% cases), though a lower percentage was seen in Switzerland (38-47\%) (1). Other conditions associated with requests include amyotrophic lateral sclerosis (ALS), multiple sclerosis, cardiovascular disease and immunodeficiency syndrome (1). Although there is some variation by country, research indicates that the typical patient receiving euthanasia or physician-assisted suicide is white, highly educated and male, between 60 and 85 years old $(1,7)$. In countries where both euthanasia and physicianassisted suicide are legal options, euthanasia is far more frequently requested $(21,23)$. One study in the Netherlands indicated that in $75 \%$ of cases, euthanasia was preferred (24).

\section{Frequency of assisted dying practices}

Information about the frequency of euthanasia and assisted death is obtained through mandatory reporting, which is part of the procedural requirement of the law (7) (Table 3). Mortality follow-back studies among attending physicians 
Table 3 Jurisdictions with assisted death and frequency of reported euthanasia and assisted suicide

\begin{tabular}{|c|c|c|c|c|}
\hline Jurisdiction & Euthanasia and/or PAS? & $\begin{array}{c}\text { Year of latest known } \\
\text { number of deaths }\end{array}$ & $\begin{array}{l}\text { Number of deaths by } \\
\text { euthanasia and/or PAS }\end{array}$ & $\begin{array}{l}\text { Percentage of } \\
\text { all deaths }\end{array}$ \\
\hline \multicolumn{5}{|l|}{ Europe } \\
\hline Netherlands & Euth and PAS & 2018 & 6,126 & $4.0 \%$ \\
\hline \multicolumn{5}{|l|}{ America } \\
\hline Canada & Euth and PAS & 2018 & $2,614(b)$ & $1.1 \%$ \\
\hline Colombia & Euth and PAS & a & a & a \\
\hline Montana & PAS & a & a & a \\
\hline Vermont & PAS & a & a & a \\
\hline California & PAS & 2018 & 337 & $0.1 \%$ \\
\hline Colorado & PAS & 2018 & 86 & a \\
\hline District of Columbia & PAS & a & a & a \\
\hline Hawaii & PAS & 2019 & 14 & a \\
\hline Maine & PAS & a & a & a \\
\hline
\end{tabular}

a, data not (yet) available; b, number of medically assisted deaths in Canada provided between Jan 1 and Oct 31,2018 (not including Quebec, NWT, YK, and NU). PAS, physician-assisted suicide.

using a random sample of death certificates were developed in the Netherlands and have also been used to investigate the prevalence and characteristics of euthanasia and physician-assisted suicide in other countries (25). According to governmentally reported data, in the first years following legalization in the Netherlands in 2002, the number of euthanasia cases became steady at just under 2,000 cases per year (26). A gradual increase starting in 2007 saw the number climb to 6,585 cases in $2017,4.38 \%$ of total deaths (26). The 2015 rate according to the Dutch mortality follow-back survey was $4.6 \%$ (27).

The Belgian federal reporting data shows 2,655 cases reported in 2019 (est. 2.4\%), which is an increase from 2,357 cases recorded in 2018, $2.1 \%$ of all deaths (28). However, the reported use of euthanasia among Dutchspeaking Belgians accounted for the majority of cases (76\%), with far fewer cases reported among French-speaking Belgians (24\%) (28). The follow-back survey in the Flanders region of Belgium, which includes a broader definition of euthanasia than the federal reporting system, found the frequency of euthanasia and assisted suicide was estimated at $4.6 \%$ of all deaths in $2013(3,4)$.

It is important to note that research in Belgium and the Netherlands has shown that not all cases of euthanasia 
and assisted death are reported so these figures are likely underestimations of the actual extent of the practices (7). Some physicians who administer opiates with the intention of ending a person's life at their request do not recognize their actions as euthanasia, and in other cases physicians do not want to follow the prescribed procedures using recommended medication because their patient does not satisfy all the required conditions or because they find the procedure overly cumbersome (29).

Luxembourg had 11 cases of euthanasia in 2017, which was $0.26 \%$ of all deaths (30). In Canada, euthanasia deaths accounted for about $1.12 \%$ of all deaths between JanuaryOctober, 2018 (12). In Switzerland, there has been a consistent increase in cases of assisted suicide among Swiss residents and residents from other countries (primarily Germany) since 2000 (19). Approximately 150-200 people from other countries travel to Switzerland every year to access physician-assisted suicide, a practice known as "suicide tourism" (31). The annual number of cases of assisted suicide in Swiss residents nearly doubled from 500 cases in 2012 , to nearly 1,000 cases in 2016 , equalling about $1.5 \%$ of all deaths (19). The mortality follow-back survey conducted in 2013 found that $1.0 \%$ of all deaths were attributed to assisted suicide in the German-speaking part of Switzerland (21).

In the US state of Oregon, which has had the longest period of legalized physician-assisted suicide, from 1998 to June $2017,1,857$ people received prescriptions for lifeending medications, and 1,179 (64\%) died from ingesting them (32). Data from Oregon during the years 1998-2015, combined with seven years of records from Washington [2009-2015] indicate that physician-assisted suicide accounted for less than $0.4 \%$ of all deaths, and nearly all years saw an increase in requests (7). In Oregon, the actual rate of deaths by request has fluctuated between $47.7 \%$ and $81.8 \%(7)$.

\section{Drugs used for euthanasia and assisted suicide}

Although physicians can use multiple types of drugs to perform euthanasia and some existing legislation specifies the use of particular drugs, those most often recommended within legal jurisdictions typically include a combination of (optional) benzodiazepine to relax the patient, followed by a high dose of a barbiturate such as thiobarbital, pentobarbital or secobarbital, which typically causes death, followed by a muscle relaxant, if required $(5,11,33)$. The clinician is often not present when the patient administers the life-ending drugs in the US, usually by swallowing a lethal cocktail, however, in Belgium, the Netherlands and Luxembourg, physician presence is mandatory (5). The Dutch Medical Association has published guidelines on recommended and non-recommended drugs making it part of the professional conduct rules (29). In Belgium, pharmacists have published guidance on specific products and dosages and best practice information has been disseminated by the Life End Information Forum (LEIF) in Flanders, the Dutch-speaking part of Belgium (29). The drugs most commonly used for physician-assisted suicide include a self-administered barbiturate to induce unconsciousness after which death results slowly from asphyxia due to cardiorespiratory depression (34).

\section{The (continued) debate around euthanasia and physician-assisted suicide}

The ethical debates related to assistance in dying are complex and persistent. Supporters contend that the practices preserve an individual's autonomy and selfdetermination during the end of life and allow people to choose a death with dignity (5). Proponents also hold that euthanasia and assisted suicide are occasionally the only option to relieve unbearable suffering and that quality of life takes precedence over quantity of life (5). Advocates cite assisted dying as an important option in the care for those who are dying, one in which physicians can facilitate death in a safe way that suicide by other methods cannot (8). Conversely, opponents argue that euthanasia and physicianassisted suicide practices violate the medical code and the Hippocratic Oath that all physicians take, result in damage to the patient-physician relationship and undermine public trust in the health care system (5). They maintain that suffering, no matter how unbearable, can be relieved with adequate palliative care and/or terminal sedation and warn that vulnerable populations including the disadvantaged and disabled will be impelled toward premature death (5). The "slippery slope" argument is also used by opponents who suggest that inevitable and undesired expansion will take place once euthanasia and/or physician-assisted suicide are legalized and the practices will result in error, abuse and infringement on the rights of vulnerable populations $(35,36)$. Religious opposition, often based on the principle of sanctity of life, is also often encountered (5).

Some of the fiercest debate is focused on assisted dying for members of vulnerable groups including those with dementia or chronic mental illness, disabilities, the elderly, 
minors, minorities, those who are socioeconomically vulnerable or are just "tired of life" $(7,35)$. Much recent heated debate has focused on the complex issue of assisted dying requests by those with psychiatric and mental disorders, sometimes through the use of an advance euthanasia directive $(37,38)$. The controversy often revolves around whether psychiatric disorders are an indication for assisted dying, the role of mental illness in motivating requests for assisted dying, the decisional capacity and competency of those making requests and what constitutes 'incurable' or 'irremediable' in the context of psychiatric conditions (37). The use of euthanasia to alleviate unbearable suffering caused by a psychiatric disorder or dementia is currently only permitted in the Netherlands, Belgium and Luxembourg (38). Since research has shown an increase in euthanasia cases among this group since 2008 there are particular concerns related to establishing mental capacity and voluntariness of the request and the increased psychological demands on health care professionals involved with these cases (38).

The Netherlands and Belgium are the only jurisdictions which currently permit the use of assisted dying in infants and/or children, but it remains intensely debated in international literature $(39,40)$. Although the requirements are stringent and assisted dying in children is rare, research has shown support among Dutch pediatricians to expand eligibility for assisted dying to children younger than 12 , and some go further to suggest that parents of children who are not competent to decide for themselves and are suffering unbearably should also be able to request euthanasia (40). Many pediatricians in the Netherlands and Belgium disagree with strict age limits for euthanasia (40). The debate over expanding assisted dying to children has been ongoing since the passage of MAiD in Canada (41). Autonomy and the capacity to consent are central among concerns for opponents (41). Although consideration is afforded to minors deemed mature enough to make informed decisions for themselves, children are often believed to lack the capacity to understand and reason and are therefore considered particularly vulnerable, though some argue that children should be seen as active agents with morally meaningful perspectives which should be considered with regard to end-of-life decision making (41).

\section{Conclusions}

While the social and political debate around euthanasia and physician-assisted suicide remains fierce and unremitting, legislation for assisted dying has expanded significantly in Europe, America and Australia over the past 20 years (42). Euthanasia and/or physician-assisted suicide practices are now legal in 18 jurisdictions (with Western Australia coming into effect in 2021), increasing the number of people with access to assisted dying to over 200 million (3). Considerable variation in terminology and frequency of use exists across jurisdictions as well as in the substantive and procedural requirements. Many countries are currently grappling with issues related to end-of-life care and new assisted dying legislation has been proposed in a variety of jurisdictions throughout Europe and the US. As access to assisted dying increases, the need for additional research into the impacts on patients, physicians, health care systems and communities is ever more relevant and pressing, as is the careful monitoring of adherence to substantive and procedural safeguards. Ongoing examination of the impact of new and expanded assisted dying legislation on members of vulnerable groups, such as those with psychiatric illness and minors, will be of particular importance $(36,40)$. With demographic, cultural and societal trends worldwide leading to increased debate about autonomy and self-determination at the end of life, assisted dying will continue to grow as a critical public health issue.

\section{Acknowledgments}

Funding: None.

\section{Footnote}

Peer Review File: Available at http://dx.doi.org/10.21037/ apm-20-637

Provenance and Peer Review: This article was commissioned by the Guest Editors (Nancy Preston, Sheri Mila Gerson) for the series "Hastened Death" published in Annals of Palliative Medicine. The article has undergone external peer review.

Conflicts of Interest: All authors have completed the ICMJE uniform disclosure form (available at http://dx.doi. org/10.21037/apm-20-637). The series "Hastened Death" was commissioned by the editorial office without any funding or sponsorship. LD serves as an unpaid editorial board member of Annals of Palliative Medicine from Jan 2013 
to Jun 2021. The authors have no other conflicts of interest to declare.

Ethical Statement: The authors are accountable for all aspects of the work in ensuring that questions related to the accuracy or integrity of any part of the work are appropriately investigated and resolved.

Open Access Statement: This is an Open Access article distributed in accordance with the Creative Commons Attribution-NonCommercial-NoDerivs 4.0 International License (CC BY-NC-ND 4.0), which permits the noncommercial replication and distribution of the article with the strict proviso that no changes or edits are made and the original work is properly cited (including links to both the formal publication through the relevant DOI and the license). See: https://creativecommons.org/licenses/by-nc-nd/4.0/.

\section{References}

1. Steck N, Egger M, Maessen M, et al. Euthanasia and assisted suicide in selected European countries and US states: systematic literature review. Med Care 2013;51:938-44.

2. Dierickx S, Cohen J. Medical assistance in dying: research directions. BMJ Support Palliat Care 2019;9:370.

3. Chambaere K, Cohen J. Euthanasia and Public Health. In: International Encyclopedia of Public Health [Internet]. Available online: https://linkinghub.elsevier.com/retrieve/ pii/B9780128036785001491

4. Dierickx S, Deliens L, Cohen J, et al. Comparison of the Expression and Granting of Requests for Euthanasia in Belgium in 2007 vs 2013. JAMA Intern Med 2015;175:1703-6.

5. Cohen J. Euthanasia [Internet]. McGraw-Hill Education; [cited 2020 Mar 10]. Available online: http://accessscience. com/content/246850

6. Rietjens JAC, van der Maas PJ, Onwuteaka-Philipsen BD, et al. Two Decades of Research on Euthanasia from the Netherlands. What Have We Learnt and What Questions Remain? J Bioeth Inq 2009;6:271-83.

7. Emanuel EJ, Onwuteaka-Philipsen BD, Urwin JW, et al. Attitudes and Practices of Euthanasia and PhysicianAssisted Suicide in the United States, Canada, and Europe. JAMA 2016;316:79-90.

8. Dugdale LS, Lerner BH, Callahan D. Pros and Cons of Physician Aid in Dying. Yale J Biol Med 2019;92:747-50.

9. Marcoux I, Mishara BL, Durand C. Confusion between euthanasia and other end-of-life decisions: influences on public opinion poll results. Can J Public Health 2007;98:235-9.

10. Braverman DW, Marcus BS, Wakim PG, et al. Health Care Professionals' Attitudes About Physician-Assisted Death: An Analysis of Their Justifications and the Roles of Terminology and Patient Competency. J Pain Symptom Manage 2017;54:538-45.e3.

11. Death with Dignity. Death Dign [Internet]. [cited 2020 Jan 22]. Available online: https://www.deathwithdignity. org/learn/death-with-dignity-acts/

12. Canada, Health Canada. Third interim report on medical assistance in dying in Canada. [Internet]. 2018 [cited 2020 May 25]. Available online: https://www.deslibris.ca/ ID/10097256

13. Schweda M, Schicktanz S, Raz A, et al. Beyond cultural stereotyping: views on end-of-life decision making among religious and secular persons in the USA, Germany, and Israel. BMC Med Ethics 2017;18:13.

14. Chapter 70.245 RCW: THE WASHINGTON DEATH WITH DIGNITY ACT. [cited 2020 Mar 10]; Available online: https://app.leg.wa.gov/rcw/default. aspx? cite $=70.245$

15. Pinedo E, Allen N, Faus J, et al. Euthanasia bill moves ahead in Spanish parliament [Internet]. Reuters; 2020 [cited 2020 May 22]. Available online: https://www.reuters. com/article/us-spain-politics-euthanasia/euthanasia-billmoves-ahead-in-spanish-parliament-idUSKBN2052C0

16. Raposo VL. Euthanasia please, we are Portuguese [Internet]. Vol. 2020. Journal of Medical Ethics; 2020. Available online: https://blogs.bmj.com/medicalethics/2020/03/05/euthanasia-please-we-are-portuguese/

17. Seymour D. End of Life Choice Bill [Internet]. New Zealand Parliament; [cited 2020 May 24]. Available online: https://www.parliament.nz/en/pb/bills-and-laws/ bills-proposed-laws/document/BILL_74307/end-of-lifechoice-bill

18. Dyer O, White C, García Rada A. Assisted dying: law and practice around the world. BMJ 2015;351:h4481.

19. Bartsch C, Landolt K, Ristic A, et al. Assisted Suicide in Switzerland. Dtsch Arztebl Int 2019;116:545-52.

20. Hyde R. Germany overturns ban on assisted suicide. Lancet 2020;395:774.

21. Dierickx S, Onwuteaka-Philipsen B, Penders Y, et al. Commonalities and differences in legal euthanasia and physician-assisted suicide in three countries: a populationlevel comparison. Int J Public Health 2020;65:65-73.

22. Al Rabadi L, LeBlanc M, Bucy T, et al. Trends in Medical 
Aid in Dying in Oregon and Washington. JAMA Netw Open 2019;2:e198648.

23. Borasio GD, Jox RJ, Gamondi C. Regulation of assisted suicide limits the number of assisted deaths. Lancet 2019;393:982-3.

24. Onwuteaka-Philipsen BD, Muller MT, van der Wal G, et al. Active voluntary euthanasia or physician-assisted suicide? J Am Geriatr Soc 1997;45:1208-13.

25. van der Heide A, Deliens L, Faisst K, et al. End-of-life decision-making in six European countries: descriptive study. Lancet 2003;362:345-50.

26. Heins $M$, Nederlands instituut voor onderzoek van de gezondheidszorg (Utrecht). Ontwikkelingen in het aantal euthanasiegevallen en achterliggende factoren. Utrecht: NIVEL; 2019. Available online: https://www.nivel.nl/nl/ publicatie/ontwikkelingen-het-aantal-euthanasiegevallenen-achterliggende-factoren

27. van der Heide A, van Delden JJM, Onwuteaka-Philipsen BD. End-of-Life Decisions in the Netherlands over 25 Years. N Engl J Med 2017;377:492-4.

28. EUTHANASIE - Cijfers voor het jaar 2019 । Volksgezondheid. [cited 2020 Mar 10]; Available online: https://overlegorganen.gezondheid.belgie.be/nl/ documenten/euthanasie-cijfers-voor-het-jaar-2019

29. Dierickx S, Cohen J, Vander Stichele R, et al. Drugs Used for Euthanasia: A Repeated Population-Based Mortality Follow-Back Study in Flanders, Belgium, 1998-2013. J Pain Symptom Manage 2018;56:551-9.

30. suicide $\mathrm{CN}$ de $\mathrm{C}$ et d'Evaluation de la loi du mars sur l'euthanasie et l'assistance au. Cinquième rapport de la loi du 16 mars 2009 sur l'euthanasie et l'assistance au suicide (années 2017 et 2018). [cited 2020 Mar 10]. Available online: http://www.sante.public.lu/fr/publications/r/ rapport-loi-euthanasie-2017-2018/index.html

31. Gauthier S, Mausbach J, Reisch T, et al. Suicide tourism: a pilot study on the Swiss phenomenon. J Med Ethics

Cite this article as: Mroz S, Dierickx S, Deliens L, Cohen J, Chambaere K. Assisted dying around the world: a status quaestionis. Ann Palliat Med 2021;10(3):3540-3553. doi: 10.21037/ apm-20-637
2015;41:611-7.

32. Hedberg K, New C. Oregon's Death With Dignity Act: 20 Years of Experience to Inform the Debate. Ann Intern Med 2017;167:579-83.

33. Beardsley C, Brown K, Sandroussi C. Euthanasia and surgeons: an overview of the Victorian Voluntary Assisted Dying Act 2017 and its relevance to surgical practice in Australia. ANZ J Surg 2018;88:956-8.

34. Sinmyee S, Pandit VJ, Pascual JM, et al. Legal and ethical implications of defining an optimum means of achieving unconsciousness in assisted dying. Anaesthesia 2019;74:630-7.

35. Lerner BH, Caplan AL. Euthanasia in Belgium and the Netherlands: On a Slippery Slope? JAMA Intern Med 2015;175:1640-1.

36. Appelbaum PS. Should Mental Disorders Be a Basis for Physician-Assisted Death? Psychiatr Serv 2017;68:315-7.

37. Sheehan K, Gaind KS, Downar J. Medical assistance in dying: special issues for patients with mental illness. Curr Opin Psychiatry 2017;30:26-30.

38. Dierickx S, Deliens L, Cohen J, et al. Euthanasia for people with psychiatric disorders or dementia in Belgium: analysis of officially reported cases. BMC Psychiatry 2017;17:203.

39. Davies D. Medical assistance in dying: A paediatric perspective. Paediatr Child Health 2018;23:125-30.

40. Bolt EE, Flens EQ, Pasman HR, et al. Physicianassisted dying for children is conceivable for most Dutch paediatricians, irrespective of the patient's age or competence to decide. Acta Paediatr 2017;106:668-75.

41. Singh HK, Macdonald ME, Carnevale FA. Considering medical assistance in dying for minors: the complexities of children's voices. J Med Ethics 2020;46:399-404.

42. Willard C. Killing and caring: is euthanasia incompatible with care? Eur J Cancer Care Engl 1997;6:40-4. 